\title{
Weaving Relatives \\ Elopement and Kinship in a Southern Brazilian Community
}

\author{
Juliana P. Lima Caruso \\ PPGAS-UFSC
}

\section{Resumo}

Neste artigo, procuro apresentar as principais discussões da minha dissertação, sobre a fuga matrimonial e as formas de parentesco em uma comunidade da cidade de Florianópolis, no Estado de Santa Catarina. O cerne deste trabalho é a fuga matrimonial, uma forma de união consensual que possibilita as uniões entre parentes. As noções de parentesco e família também são abordas neste artigo, assim como a experiência realizada com a MaqPar(Máquina do Parentesco) e outros programas computacionais que possibilitaram novas visões sobre o campo. Entre as percepções sobre o parentesco, as questões de substância e convívio entrelaçam com a prática da fuga e as "redes empíricas".

Palavras-chave: fuga; parentesco; família; redes empíricas

\begin{abstract}
The aim of this article is to show the main discussions of my work on Elopement and some kinds of kinship in a community in the city of Florianópolis, Santa Catarina state. The core of this work is the Elopement, a form of consensual union that allows marriage between relatives. Notions of kinship and family are also discussed, as well as the experience with MaqPar (acronym for machine kinship) and other computer programs which enabled new insights into this field. Among the perceptions about relationships, substance and coexistence issues are interwoven with the elopement and empirical networks.
\end{abstract}

Keywords: elopement; kinship; family; empirical networks. 


\title{
Weaving Relatives \\ Elopement and Kinship in a Southern Brazilian Community
}

\author{
Juliana P. Lima Caruso' \\ PPGAS-UFSC
}

Bobbin lace work in Costa da Lagoa is done on a round cushion filled with banana straw. A paper or cardboard template known as a 'pique' is carefully pinned to the cushion. After the lace pattern is marked, the lace-makers choose their pairs of bobbins (small round, wooden spools), wind them with thread and begin weaving the chains that connect the different flower, leaf and puff stitches. The stitches are interconnected to form a flower pattern. When the flowers are attached to the chains and other stitches, a wide strip is formed. This strip is also darned to finish off the lacework. A lace piece may be either the 'final artwork' or it may be attached to another piece and the work continued.

In the community of Costa da Lagoa, being a member of a family implies being part of a lace-like network. Elements such as family, eloping couples and 'being a relative' intertwine in lace-like fashion.

The community of Costa da Lagoa where this study was conducted ${ }^{2}$ is located in the northeastern portion of the island of Florianópolis, in the state of Santa Catarina. This region is approximately nine kilometres long and is one of the neighbourhoods surrounding the Lagoa da Conceição (Conceição Lagoon). The only ways of reaching the community are by boat or by overland trail, explaining why the region's inhabitants often talk about their isolation from other neighbourhoods of the city which are well served by roads. Two trails connect Costa da Lagoa to neighbouring areas, one leading to Canto dos Araçás $7.5 \mathrm{~km}$ away, the other to Ratones, $3 \mathrm{~km}$ distant.

Today these trails are seldom used. Boats operated by two cooperatives of

\footnotetext{
1 I wish to thank the IBP (Instituto Brasil Plural) for supporting the translation of this article. The research is part of "Recreating Kinship: the economy of the family and matrimonial exchanges", a research project coordinated by Dr. Miriam Hartung and also linked to the Centre of Fundamental Studies in Anthropology (A-Funda).

2 This article presents the results of my MA dissertation entitled "Laces of Life: Marriage Relations in Costa da Lagoa", defended at PPGAS/UFSC in 2011.
} 
local residents provide the main form of transport. The first, Coopercosta, is located $3 \mathrm{~km}$ away in Rio Vermelho state park and serves the route most used by tourists visiting the community. The second, Cooperbarco, mainly serves Lagoa's residents, following a route lined with boat stops at wharves numbered from 1 to 23 , leading, into Costa da Lagoa.

Long before Costa da Lagoa was spatially demarcated by the boat stops, the area was already divided into 'villages'. Nowadays there are six. Heading northwards, the first village is Vila Verde, followed by Praia Seca, Baixada, Vila (the community's centre), Praia de Fora and Praia do Sul. Beyond the latter, further north still, there is a currently uninhabited area known as Prainha, where the locals hold parties and barbecues. Once a thriving village, the area was home to flour mills until the beginning of the $20^{\text {th }}$ century, when they were shut down and sold to 'outsiders'. ${ }^{3}$

Costa da Lagoa has experienced a number of profound changes over the last few decades. Like the rest of Florianópolis, the region was colonized by immigrants from the Azores in the mid- $18^{\text {th }}$ century. From the $19^{\text {th }}$ to the mid- $20^{\text {th }}$ century, the local subsistence economy revolved around agriculture - cassava, maize, beans, sugarcane and peanuts - and artisan fishing. As Gimeno (1992) explains, the system was based on familial cooperation. When more than one family was involved, fish catches were divided according to the 'half' system, while agricultural produce and flour production were divided into 'thirds'. From the 1930 onwards, residents say several factors contributed to the decline in agriculture: pests, soil exhaustion and the need for financial investment. As a solution the male workforce in Costa da Lagoa turned to offshore activity to obtain income for the community and thus began working on large fishing trawlers sailing from the ports of Rio Grande do Sul and São Paulo.

The 1980 s saw the beginning of tourism and real estate expansion in Florianópolis. From this point on the city grew rapidly and, in the wake of its urban expansion, began to attract 'outsiders' from different cities and states. Tourism established itself as a key source of income for the city. But unlike other neighbourhoods where investments were channelled into hotels, clubs and party venues catering for seasonal tourism, Costa da Lagoa has fostered

3 The categories of 'outsider' and 'native' (or 'manezinho') are frequently used respectively to refer to people who were born in the neighbourhood/city and individuals coming from other cities/states/ countries. 
eco-gastronomic tourism centred around its restaurants. Today, while outsiders form the majority of the population in other areas of the city, in Costa da Lagoa they remain a minority. Even in the bars and restaurants, the staff are usually family members or neighbours of the owners.

Jobs and chores in Costa da Lagoa are shared between the residents and more particularly family members. As mentioned above, in restaurants the owners themselves, usually a couple, will work together with their sons, daughters-in-law, sons-in-law and neighbours. Transportation services are provided by the locals, who are also responsible for catching the fish that supply the local restaurants. Domestic work and care for children and elderly relatives are also shared among family members, especially those living in the same home.

\section{Threads of the Lace: Family Ties in Costa da Lagoa}

In Costa da Lagoa, the term 'family' has a range of meanings. Whenever I asked local residents about the meaning of the word during my research, I was told that "all [native residents] are one and the same family" and, at the same time, that "each village has a few families". In the latter case, people told me I could "see each of the families" and would point to clusters of houses on a hillside. In addition to these two acceptations, the word 'family' may also be used to refer to the unit constituted by a father, mother and children living under the same roof.Although expressed less frequently, the first conception of the term - that all residents are part of one single family - becomes evident when we turn to the community's festivities. For birthday parties, prior invitations are rarely made. As 52-year-old Agenor explains, a local commonly invites everyone he or she comes across on the trail. Invitations cannot be sent to specific people - everyone must be invited. The same logic applies when a community member dies. Any dance balls or other festivities being held in the neighbourhood are suspended. The idea that all community members are relatives also appears in affirmations by residents like: "if you took blood samples of everyone here, you would see that we are all related".

This manner of conceiving a connection between all community members as though everyone were related by blood became very clear from 
the results of the empirical network analyses I conducted using MaqPar4. Although only a sample of the community was analyzed (425 residents 5 from a total of 778), when a graphic image was generated of the consanguine and affinal relations existing between the individuals included in the genealogical survey, we observed that a multiplicity of relations had been established from 130 marriage unions - almost all the result of elopement. The image below, generated from MaqPar data and drawn by $\mathrm{PUCK}^{6}$, shows the empirical network for Costa da Lagoa:

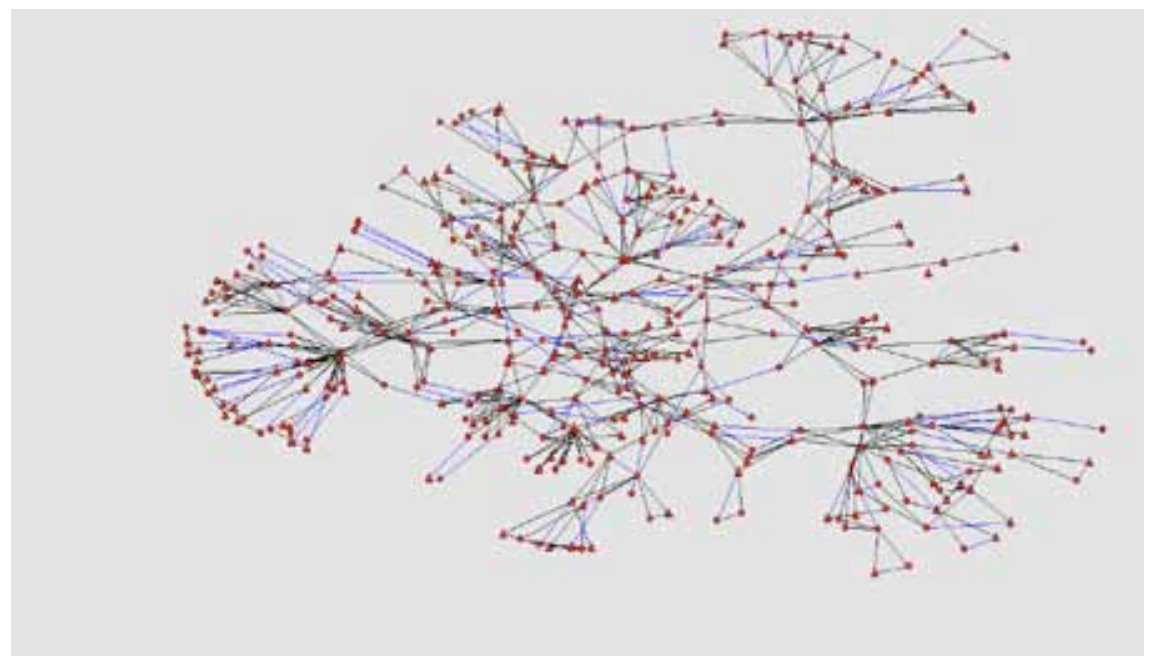

Figure 1 Empirical Network, Costa da Lagoa

Resembling lace work, the above network is composed of delicately sewn elements and layers. Family is one of these elements composed of layers. As well as the notion that this term extends to 'all residents', in Costa da Lagoa

4 The MaqPar program (an abbreviation of Máquina de Parentesco or Kinship Machine) was created by Marcio Ferreira da Silva at USP and João Dal Poz at UFJF. The software analyses empirical kinship networks, allowing us to observe and describe phenomena otherwise difficult to perceive. Because its programming is based on graph theory, a MaqPar reading shows how individuals (male and female) connect by blood and affinity.

5 The genealogical database of residents in Costa da Lagoa included personal data on each individual (an individual four-digit number, name, sex and parents' names), as well as relevant data such as place of birth, current address, last name and other residential addresses and places of origin. These fields were added to enable analyses of endogamy, exogamy and marriage changes.

6 PUCK (Program for the Use and Computation of Kinship data), found on http://www.kintip.net/, was developed by Klaus Hamberger as part of the project Traitement informatique des phénomènes de parente em anthropologie et histoire (TIIP), of the research group Traitement Informatique de la Parenté(TIP), directed by Michael Houseman and Cyril Grange (Hamberger, Houseman and Grange 2009). 
the term also denotes the 'village family', or the family that can be seen. By 'seen' they mean that a group of houses surrounds the home of the eldest couple, all located on the same property. These houses belong to the sons, nephews and even grandsons of the plot's owners. This type of organization can be defined as a "kith and kin arrangement".

The family group comprised by a couple, their children and the spouses of the latter is usually identified and referred to by the father's surname, since he is the owner of the land on which all the houses stand.

The couple's sons very often remain living on their parents' property, bringing their wives to live with them. The couple's daughters go to live at their husbands' home once married. It is therefore common for sons to be living next to their parents while daughters are scattered across different villages of Costa da Lagoa, living with their spouses' parents. There are a few exceptions to this residential arrangement, especially when the couple has few or no sons. In this case, the couple will receive their daughter's husband to live on their property.

The village family also encompasses what the literature calls a nuclear/ marital family. For the residents of Costa da Lagoa, this is the most important level. These are the relatives who share the domestic chores and help take care of the children and elderly. Gimeno (1992) calls this family organization a 'mountain family'. She describes this type of family as follows:

"[the mountain family has] a rigid definition of the social and productive roles of each of its members. Patriarchy is one of its strongest characteristics. The sole owner of movable and immovable property, the patriarch is the repository of all organization and coordination of the family's productive activities in its various segments: agriculture, cattle breeding and fishing”. (Gimeno 1992:11)

The mountain family described by Gimeno (1992) has changed considerably over the last two decades, especially in terms of family support. But the division of labour and the way of caring for children and the elderly have remained unchanged. The children of working mothers usually stay with the women of the family while their mother is out at work. The elderly are cared for by nearby relatives, especially when one of the spouses dies, and particularly when that spouse is the wife, and the man is bereaved. Widows rely on the support of their sons and daughters-in-law to do the shopping and go into town. In the case of widowers, fear of suicide takes over the family. Since 
instances of suicide are far from unknown, in the first months after the death of a man's wife the family will keep a close eye on him - in some cases, they will actually remove all wiring and sharp objects from the house - and, after a few months, his female relatives will take over the daily chores of his house for the remainder of his life.

As we shall see later in this article, it is living together on the same property that makes these family members truer relatives than those living in other villages. The act of living together may on some occasions be translated by the word 'knowledge'.

Most of the village families of Costa da Lagoa are the product of a type of marital union known as elopement or 'stealing'. From the 425 people included in the genealogical survey conducted during fieldwork, only 7 couples (14 people) from a total of 130 unions established over 6 generations were married by means other than elopement, which represents less than 4.8 per cent of the population studied. Among these 130 unions, 77 per cent of residents married 'native' individuals, that is, members of local Costa da Lagoa families. Furthermore, if we take into account only those spouses whose grandparents are still alive, the number of all-native unions rises from 77 to go per cent. It is this type of union - which in some cases could be defined as restricted exchange - which over successive generations has formed a dense family network encompassing the entire community.

It is interesting to note that elopement is less common than civil or religious marriage in other neighbourhoods of Florianópolis where research on the practice has been conducted. In these areas, such as Caieira Barra do Sul, Cachoeira do Bom Jesus and Rio Vermelho, running away is less frequent than in Costa da Lagoa and is usually done as a way of overcoming hindrances such as the prohibition on marriage among relatives seen as 'close'.

\section{The Petals of the Lace Piece: Running Away}

The elopement process can be summarized as follows: the young man meets his girlfriend at a pre-arranged location and they run off together, very often to a relative's house. They stay there for a period that can vary from days to weeks. After this period is over, the runaway couple returns to the girl's home to fetch her belongings or to make their union 'official' with her family (the family may receive the couple and either accept or reject their decision). The 
couple then goes off to live in their own home. It is from this moment on, after their return, that the two are considered married by the community and family. The couple often makes their union official by getting married in a religious or civil ceremony. This is roughly how elopement takes place in Costa da Lagoa and in other areas of Brazil.

Consensual unions are not a new practice in Brazil. Known as elopement and cohabitation, these forms of consensual union figured in the past among the main forms of marriage without civil or religious ceremony. According to historiography, consensual unions - classified as illegitimate - were far from being irrelevant in number. On the contrary, this was the most common form of marital union in the $18^{\text {th }}$ and $19^{\text {th }}$ centuries, particularly in the south and southeast of the country (Samara 1985, Nizza 1984, Arend 2001). Precisely because of the recurrence of consensual unions such as elopement and cohabitation, the Catholic Church and the State/Crown established severe punishments to try and stop such practices in Brazil.

The residents of Costa da Lagoa explain that running away has always been common practice and that reports of such cases have existed as far back as anyone can remember. The practice is referred to by a series of names, depending, first of all, on the gender of the person discussing it. From the male viewpoint, running away is an instance of theft. The action is their prerogative: they do not run off but rather steal their wives. From the female viewpoint, they either run away or are stolen. While these are the main terms used by men and women to refer to the act of eloping to get married, there are other, less common expressions. When a man has stolen a woman, people may also say that a 'goose chase' or an escape has taken place. A runaway woman may be said to have married "with her little bundle (of clothing)" or, nowadays, to have "stayed together (with someone)".

Irrespective of the name given to the practice, elopement is an important moment in the lives of the couple involved, even if they later decide to wed in church or at the registry office. Some couples celebrate their wedding anniversary on the date they ran away. In Costa da Lagoa, the golden wedding anniversary is counted from the date of the elopement rather than the date of any subsequent wedding. The couple is likely to not even remember the latter. When asked, people will promptly say "It has been 20 years since I ran away". For 80-year-old Dona Ivone, February $22^{\text {nd }}$ is her wedding anniversary - the day she ran off with her husband-to-be. For the few couples who 
were not married by elopement, it is the actual wedding date that counts. From the 7 official unions found in the survey, 5 were civil marriages and, of these, 4 dated back to the first decades of the $20^{\text {th }}$ century. When we look at the other options available for couples wishing to get married, a preference for civil marriage, with or without festivities, becomes clear. Dona Sabrina, 78 years old and the granddaughter of slaves, recounted that her two sisters were married in small ceremonies and that a Justice of the Peace was asked to perform the weddings.

Other similar reports describe the wedding ceremonies as modest celebrations with a Justice of the Peace presiding over the event. Only the most recent weddings have been celebrated in a Catholic church. This raises various questions. Why was there a preference for civil marriage among the couples that chose to formalize their union? If the choice was either to marry in church or to have a civil wedding, why did most couples opt to run away? To answer these questions I decided to take a closer look at the elopement process.

Although earlier in this article I presented a 'shared repertoire' of reasons that explain elopement as it generally occurs, in Costa da Lagoa the process requires a few extra steps to be completed. First 'conversations', as the locals call them, take place in which the couple discusses details of the escape plan such as the date, place and time when they will meet, and both parties seek reassurance from the other as to the decision made. According to Seu Vicente, 72 , the conversation he had with his own wife before she ran away with him went as follows:

“At the end of four years, I said: 'How about we go away, run away?' I asked her: 'Do you really like me? Aren't you going to put one over me? Then let's go.' That's how the talk went (...)". (Vicente)

As soon as the details are settled, both parties begin to prepare. Sometimes the fiancé will arrange to stay at his father's house or a relative's during the escape. The girl will pack a bundle of clothes - and a dowry if she has one - and she may warn her friends, cousins and even her mother of her decision. Once the preparations are finished, the couple will meet at the predetermined rendezvous and run off together. There are reports of couples leaving by boat, on foot and even just walking off as if nothing unusual was happening.

As the locals explain, the partners' first night together, when they 
consummate the union, represents their biggest act of commitment.

For the women now aged between 50 and 80, this was the night when they lost their virginity. For the women under 50, this was not always the case. Irrespective of this particular aspect, from the couple's first night together the union is sealed to the point of no return. After the first night "there is no way back", say the locals.

In the literature examining this type of marital union, there are cases of couples taking up accommodation in different neighbourhoods and cities during the escape (including the "first night together"). However, couples will usually stay with a relative of the fiancé. In Costa there are no reports of couples leaving the city. All reported couples stayed either with a close relative of the fiancé, or at flour mills or even in their own future residence ${ }^{7}$ when the fiancé had already finished building the house with this purpose in mind. Very often they stayed at the young man's parents' house.

The escapade ends, so to speak, when the couple appears before the bride's parents. When the parents and relatives accept the marriage, this reencounter is followed by a collective meal such as lunch. But when the news is not well received, sometimes the girl's father or other family members will refuse to leave the house to greet the spouses. In the neighbouring village of Rio Vermelho where I conducted research for my undergraduate thesis, the act of running away was itself viewed negatively. The family members' discontentment began the day the girl eloped, and in some situations the bride's father would publicly bemoan the occurrence. Unlike Costa da Lagoa, Rio Vermelho has few reports of elopement.

Running away in Rio Vermelho is associated with potentially forbidden unions, the main reason for prohibition being blood relations between the partners. When a union involves cousins, especially matrilateral, whose genealogies (generations +1 and +2 ) include another couple formed by cousins, the union is almost invariably surrounded by reports of very grave events interpreted as 'divine punishment'. Unions such as these were accredited

7 Although a house is an important element of the elopement process, it is not indispensable at the outset. Couples often stay with relatives until their own house is completed. However, when a young man is building a house this is seen by his relatives as an indication of impending marriage/elopement. This was the case with Mariana, 28 years old, and Danilo, 32, who were just completing construction of their house while I was doing my research. Several times I heard members of their family and the community joking about it and asking them when they would run away. 
with the sudden, inexplicable deaths of 18 children in the 1960 . Some Rio Vermelho residents refer to the events as the 'incest disease' or 'blood disease'. Couples formed by cousins whose parents or grandparents are also cousins are cited as "exemplary cases of the disease". The disease is supposed to be the reason behind offspring with physical and behavioural problems.

In Costa da Lagoa, on the other hand, unions between cousins or close relatives are just as likely to be accepted as rejected. Whether a union comes to be viewed with sympathy or animosity depends on the category 'knowledge'. Knowledge refers to relatives living in the same property, sharing the same food and thus having a closer relationship and more intimate knowledge of each other. But before discussing this knowledge, I need to explain the main interpretations given to the elopement process.

According to the authors who have addressed the issue, either directly or indirectly, the probable reasons for elopement are diverse. The main three attributed are: financial hardship, preservation of the family's or girl's honour, and marital prohibitions.

Among those authors who associate elopement with financial hardship on the part of the couple or of the bride's family, we can cite Lupi and Lupi (1985), Arend (2001), Maluf (1993), Gnaccarini (1989), Woortmann and Woortmann (1993), Gimeno (1993) and Samara (1985). In their study of Rio Vermelho, Lupi and Lupi (1985) see elopement as a way of sparing the couple and their parents from the expenses involved in holding a ceremony, purchasing a plot of land and providing a dowry. Maluf (1993), in his study of witchcraft and witch doctors in the Lagoa da Conceição neighbourhood, explains that running away may be justified by

"the fact that the families do not have enough money to host a wedding celebration. All of the fiancé's and bride's savings are destined to providing a trousseau (the bride's dowry) and building a house." (Maluf 1993:26)

Gimeno (1992) offers no specific reason for the practice of elopement in her study of Costa da Lagoa. According to the author, running away or 'stealing the bride' is part of the reality of a period with less monetization of the local economy and a community dependent primarily on subsistence agriculture. Woortmann and Woortmann (1993) also see the act of running away as a manifestation of the parents' inability to offer a dowry or cover the cost of a wedding. For all the authors, running away is a 'staged' move aimed at 
preserving the girl's honour and that of her family. The fiancé's relatives urge him to take action and by so doing, Woortmann and Woortmann argue (1993), preserve the honour of the girl's underprivileged family.

However, this explanation is not plausible in Costa da Lagoa. As mentioned earlier, only seven of the analyzed couples had an official civil or religious wedding. Among those wives who were married in a civil ceremony, some were daughters of formers slaves whose families had very few possessions, and others daughters of land and mill owners. The first had a preference for civil marriage, while the majority of the privileged daughters opted to elope. So the question remains: why did these rich girls choose to run away? Adopting a historiographic approach, it became clear that economic factors were not the only reason behind consensual unions: a blood relation between the couple was another key element.

The historiographic analysis took into account both the family's lack of economic resources and the obstacles imposed by the Catholic Church and the Crown on the act of marrying in Brazil. Arend (2001), Gnaccarini (1989) and Samara (1985) place elopement next to cohabitation and common-law marriage. For them, each is a particular form of the more general 'consensual union'. Consensual unions are motivated mainly by financial hardship on the part of the spouses and their families. Samara (1985), analyzing elopement and common-law marriages in the $18^{\text {th }}$ and $19^{\text {th }}$ centuries among the more destitute populations living in the state of Sao Paulo, concluded that this type of union was a consequence of the lack of resources to hold a ceremony and festivities. Likewise Arend (2001), in her research into marriage and cohabitation in the late $19^{\text {th }}$ century in Rio Grande do Sul, shows that elopement was not an exceptional event and that lack of resources was often the justification offered.

In her book Sistema de Casamento no Brasil Colonial (The Marriage System in Colonial Brazil), Nizza (1984) shows not only how relevant consensual unions were in Brazil at the time - and particularly in Sao Paulo - but also explains that this type of union underwent a change of status during the period. The author informs us of the innumerable difficulties, both ecclesiastic and bureaucratic, that confronted a couple wishing to marry at the time. After the Trento Council (1545-1563), cohabitation began to be punished by very severe sentences ranging from excommunication in the case of 'grave sins', to expulsion from the city (for women) and the payment of fines. If the couple insisted 
on carrying on with the sin, they could be deported to Africa. Such surveillance and control were possible because there was a clearer understanding of what defined common-law marriage: publicity and cohabitation.

Later, the Philippine Ordinations (1769) changed the status of commonlaw marriage, which began to be punished less severely by civil law. At that point, it was more important to repress marriages that failed to obtain the consent of their parents (the father's permission was mandatory for girls under 25) and outlaw unions between blood-related partners. The Philippine Ordinations established the following punishments for cohabitation between relatives:

"[...] death by fire for those committing incest with ascendants or descendants; natural death for those committing incest with a sister, daughter-in-law, mother-in-law or stepdaughter; a 10-year deportation to Africa for those committing incest with an aunt, cousin or other more remote relatives." (In: Nizza 1984:127)

As Nizza (1984) explains, although the Church over time reduced the degree of kinship for which marriage was forbidden, marriages between relatives (or couples prevented from marrying for other reasons) depended on the payment of 'matrimonial dispensations' and the observance of various obligations imposed on the couple. Ferreira (2006) in his research on the formation of the district of Santo Antônio de Lisboa (1780-1960) in the western region of Florianópolis, attributes a purely economic reason to the practice of elopement:

"[...] we can observe a particular custom that is practiced by the poorest in the parish which was not practiced back in the Azores: kidnapping, actually called 'running away' in the region. To this day, it is common for a couple to run off together and not get married until their first baby is born and they need to baptize it." (Ferreira 2006:202)"

Like Nizza (1984), Ferreira shows that elopement or kidnapping was a practice legally backed by the laws of the Kingdom, which allowed couples to run away together and later escape punishment from God and the Kingdom by getting officially married. Ferreira's study (2006) contains a highly relevant piece of information, found in the wedding registries of the parish of Santo Antônio de Lisboa, which can help us understand elopement in Costa da Lagoa. The records show that during the first 20 years of the Azorean occupation in the 
region, no children were born to unmarried parents. Birth out of wedlock begins to appear mostly in the $19^{\text {th }}$ century with the records of natural born children indicating that their parents were united by consensual union:

“(...) of 2,411 families with registered dates of marriage, in 212 cases marriage took place after the birth of the couple's first child. It is thus common to find baptism records where the first child is registered as natural and the second as legitimate. [...] In the records of the first 20 years of the period analyzed, all within the $18^{\text {th }}$ century, we found no cases of marriages having taken place after the first child was baptized. However, in the $19^{\text {th }}$ century these occurrences began to increase in number and became very commonplace in the last quarter of the $19^{\text {th }}$ century and the beginning of the $20^{\text {th }}$." (Ferreira 2006: 203-204).

Turning the second line of interpretation, we find authors who associate elopement with protecting the honour of those involved. As mentioned earlier, Klass and Ellen Woortman (1993) consider running away to be a 'social enactment' designed to preserve the honour of the family and the girl. As they put it:

"The elopement and the 'community of good faith' involved in it, which includes the young couple, their parents and the relatives who lodge the runaway couple $[. .$.$] is therefore a kind of social enactment similar to the auction [...]$ that is, the chagrin caused by the girl's act avoids an even greater shame. It cannot be repeated enough that the girl's honour, although she is no longer a maiden, is preserved (...). (Woortmann \& Woortmann 1993:119)

For Pitt-Rivers (1979), the question of honour in each culture is generally structured in a way that can be identified in its institutions and habitual valuations. "It is accepted", he writes, "that the young man who is facing opposition from the girl's parents should force them to give him her hand by running off with her to spend the night together. After that, her parents' acceptance and a wedding is the only way of recovering honour" (ibid: 53).

Staying with those authors who view elopement as an attempt to preserve honour, we can cite Raquel Wiggers (2006) and her research on the Caieira Barra do Sul neighbourhood in the southern region of Florianópolis. As the author explains, there are only two ways of getting married in this area: "either with or without a ceremony", the latter being a reference to elopement. In this case, Wiggers (2006) shows that marriage brings 'chagrin' 
to the families involved.

For Silva (1994), who also studied the practice of elopement in Florianópolis, more precisely the Ponta das Canas neighbourhood, running away is primarily intended to preserve the family's and girl's honour (her virginity). While these are the main reasons for elopement, the author adds a third, also given earlier in this article: a lack of the resources needed to pay for a wedding celebration. She writes:

"When elopement takes place, there is a feeling of shame for being unable to provide a wedding celebration. The honour of the runaway bride's father is not recognized and he internalizes this fact in the form of shame. Shame and honour are deeply connected.” (Silva 1994:45).

In this paper I suggest a third interpretation. Although I do not exclude protection of honour and lack of resources as valid reasons for running away, I would add the proposal that elopement is a way of circumventing marital prohibitions. If, in the previous research conducted in Rio Vermelho, elopement appeared as a means for cousins to get married, in Costa da Lagoa it follows a superficially different but essentially very similar logic.

When trying to figure out who runs away to marry whom in Costa da Lagoa, I was able to observe that a large percentage of runaway couples were close relatives or cousins. By using MaqPar ${ }^{8}$ I was further able to detect the recurrence of cousin couples in the same family lineage. From the moment I was able to 'visualize' the type of relative that is usually chosen as a marriage partner, the category 'knowledge' began to make more sense in the analysis.

Among the cases analyzed in this study, seven unions corresponded to $\mathrm{A}_{1} \mathrm{C}_{1}$ rings, indicating blood-related couples. From these seven unions, four were found to be repeated cases of blood-related couples in one family. The other three were unions between parallel and cross $^{9}$, matrilateral and

8 A brief presentation of MaqPar will suffice here. Based on graph theory, MaqPar is a computer program designed for formal kinship analysis that enables the researcher to explore and visualize an empirical network, while at the same time allowing the user to determine which relatives and affinal kin are involved in a union by means of the rings identified by the software. In this research I worked with three cycles: $\mathrm{A}_{1} \mathrm{C}_{1}$ (one affinal kin and one blood-related relative connecting the couple), $\mathrm{A}_{2} \mathrm{C}_{2}$ (two affinal kin and two blood-related relatives connecting the couple) and $\mathrm{A}_{3} \mathrm{C}_{3}$ (three affinal kin and three bloodrelated relatives connecting the couple). In these cycles, known as rings, A represents affinal kin and C blood-related relatives, and the links surrounding and connecting a union are traced between them.

9 By parallel cousin I mean ego's parent's same-sex sibling's child. By cross-cousin I mean ego's parent's opposite sex sibling's child. 
patrilateral cousins, all first degree. It is interesting to note that three of the seven unions were seen by the community and family members "in a bad light". In one case, family members told us they even tried to persuade the couple not to elope. Years later, the marriage supposedly led to the girl going insane and consequently leaving her husband.

More numerous than the $\mathrm{A}_{1} \mathrm{C}_{1}$ rings, the $\mathrm{A}_{2} \mathrm{C}_{2}$ rings showed that several unions were part of restricted and directed exchanges. In this type of union, the alliances connecting two or three families are replicated in several generations. The study revealed several examples of cousin or sibling exchange. In some cases there were clear exchanges between two families, with one having received, for instance, two sisters in one generation and received or been given the children of these unions in the next. The $\mathrm{A}_{2} \mathrm{C}_{2}$ rings shed some light on the exchange system in Costa da Lagoa. Marriage between cousins was not considered a problem so long as the cousins did not live on the same property. The type of cousin - whether patrilateral or matrilateral, parallel or cross - did not matter, provided they lived on different areas of land.

Following this logic, the even more numerous $\mathrm{A}_{3} \mathrm{C}_{3}$ rings showed generalized and directed exchanges between three or more families. Unions connecting two cousins from the wife's family with two cousins from the husband's family appeared as significant. The cycles also help us understand exchanges between families and villages, as shown in the figure below:

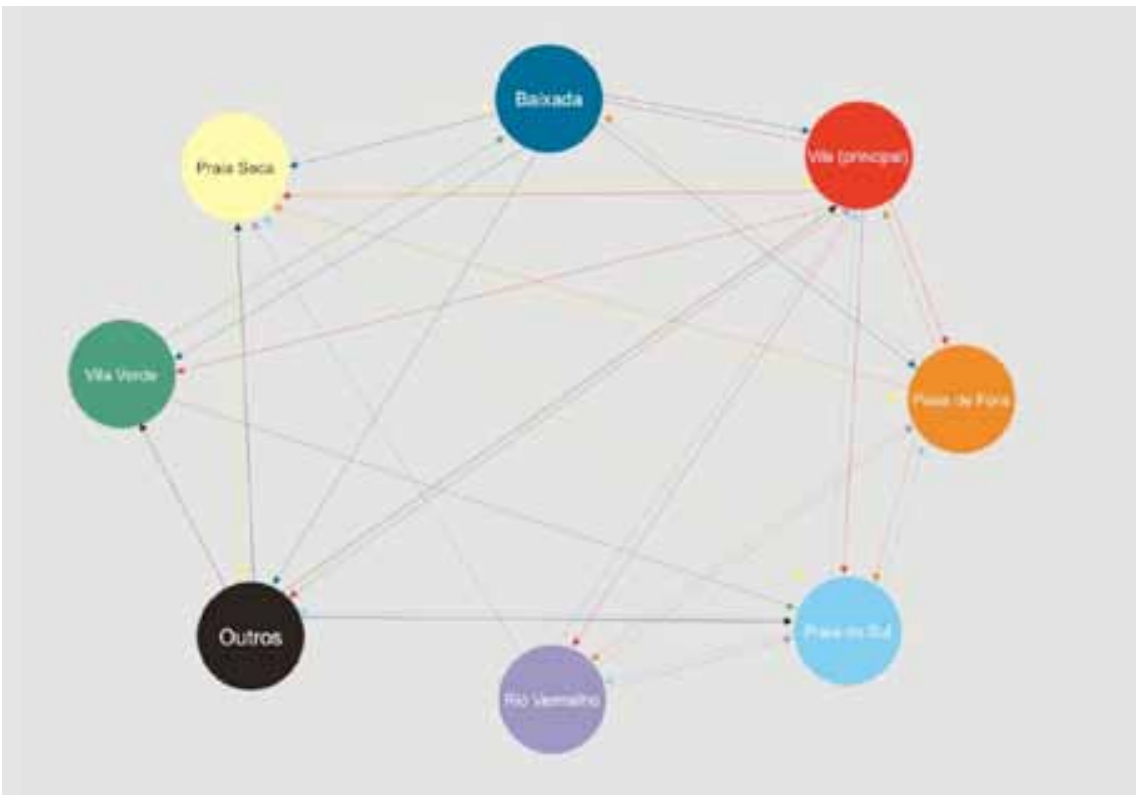


The MaqPar genealogical data analysis helped shed light on two of the questions motivating this study: which people are chosen as marriage (elopement) partners and, to the extent that this question is answered, which cousins or relatives are least accepted as spouses?

As described earlier, the unions that are least approved by the Costa da Lagoa community are those between very closely related individuals, particularly when the couple has a lot of 'knowledge' of each other. These are the most forbidden unions. While in Rio Vermelho people believe that marriages between relatives can provoke divine punishment, in Costa da Lagoa it is marriages between individuals possessing 'knowledge' of each other that are believed to be unworkable. In both cases, illnesses affecting the couple's children or the spouses themselves are blamed on the type of marital union.

Françoise Héritier's suggestion (1992) that some marriage prohibitions result from something like an accumulation of substances that generated a short-circuit has proven helpful in terms of understanding elopement in Costa da Lagoa and Rio Vermelho beyond issues of money and honour. An accumulation of knowledge, an excess of kinship, seems to lie at the origin of these prohibitions - or, if we want, at the origin of the disapproval of certain unions. It is possible that something similar to the phenomenon that inspired Héritier's (1992) notion of second-type incest is at work in the communities under study. According to the author ${ }^{10}$, the idea of a short circuit or contact is produced by the relationship between two (or more) blood relatives seen as identical and by sharing substances.

The problem with consanguineous marriage cannot be reduced simply to the position/classification of the genealogical relationship. The problems caused by unions between relatives are at their most acute in cases of knowledge, that is, when the couple has lived in the same house, or close by, and shared meals. This is considered dangerous. ${ }^{1 " W i t h}$ rare exceptions, the living

10 Françoise Héritier's (1992) concept of second-type incest is not universal in the sense of its prohibition. However, the prohibition applies to both blood relatives and affinal kin. So when addressing the issue, the author extends her explanations about moral interdictions and prohibitions to, for instance, a man who marries two sisters (this is done alternately and is known as sororal polygyny). It should be added that it is not just second-type incest that may have effects on the spouses and the society. For LéviStrauss (2009), the prohibition of incest is universal because all societies have some form of marriage regulation. In this sense, the rule that prohibits incest favours exchange which, for Lévi-Strauss, is the condition of social possibility, whereas incest is a break in the exchange system.

11 The notion of 'accumulation' is also present in other spheres of the life of residents of Costa da Lagoa. According to elder members of the community, women should not eat stingray during their menstrual 
arrangements in the areas under study exhibit a patrilocal tendency, resulting in a more intense co-existence between patrilateral parallel cousins. However, this same home-based arrangement both allows and forbids marriage between relatives. When two sisters marry two brothers, their children are not allowed to marry between them. Sometimes a young man from a big family with many sons will marry and move to his father-in-law's property, but when his own son marries his patrilateral cousin, the union will be well received by everyone.

'Knowledge' in the context of Costa da Lagoa may be comparable to what some authors call consubstantiality. Janet Carsten (2000) describes the roles of commensality and daily interaction in the establishment of kinship ties. Bonds are established by sharing diverse substances, among them food.

Moreover, as Strathern suggests (2006), the sharing of substances creates kinship ties between individuals for whom marriage is forbidden. According to the author, the mother's blood or body does not nourish the child, since there is no transformation of the child's substance except through semen. It is by enclosing substance that the woman's body duplicates the male body. This view of kinship shows that:

"More than the gender of the transacted item is established: its particular kinship source is also significant. Or rather, those kin relations establish its gender. Wives' husbands must displace wives' fathers as procreators. Semen must be produced outside the woman's body in order for it to be different from the milk/ semen/paternal substance of which she herself is also constituted, and the community of males detaches itself from communication with females to effect this separate production. (...) here the circulation of semen produces persons in the variety of kinship relations just mentioned. (Strathern, 2006:325-326)

For Hutchinson $(2000)^{12}$, blood, breast milk and sperm are substances that create kinship bonds between people when shared. However, the fusion of these substances takes place both during the 'production' of the child - milk and sperm - and during contact with and circulation of the food

periods because the fish also menstruates and this causes problems if the woman wants to have children. 12 Hutchinson's work among the Nuer should be recalled here, despite the physical and contextual distance. 
- commensality. In addition, as Helen Lambert (2000) ${ }^{13}$ points out, the substances that make up the child (which give men more right over children), such as bodily fluids, must be 'complemented' with breast milk to reinforce kinship with the mother and strengthen her feelings for the child.

In Costa da Lagoa, unions between two individuals with a lot of knowledge of each other are censured, when not prohibited entirely. However, irrespective of this impediment, there are cases of elopement, and thus marriage, between relatives considered to be very close - relatives who have shared a home and food. In all the reported cases of marriage between partners with a lot of 'knowledge', the couple was not welcomed by the family members, nor invited for a reception meal symbolizing their return to the heart of the family. There was no sign that the unions had been accepted by all.

As I have tried to demonstrate, while in one case a matrilateral cousin with distance I is prohibited because he shares excessive knowledge with his wife, in another case a cousin of the same type may be responsible for the union being seen in a good light. This dynamic, which makes it possible for a particular type of relative or affinal kin to be a 'good catch' in one generation and quite the opposite in another, indicates a (de)construction of the kinship dynamic that operates on the basis of rules of residence.

However, what I call a deconstruction of family ties involves the annulment of close kinship for (usually) matrilateral relatives. Elopement can therefore be considered to enable this type of union, which has always been condemned by the church (although the degree of this condemnation has varied over time), and enables marriages that are feared by members of the Costa da Lagoa community. But elopement also seems to have another role in endogamic unions, as they are called: namely, to distinguish, within the larger family group, who is and who is not marriable. In other words, within a group of people generally classified as relatives, the residents of Costa da Lagoa are able to differentiate between closer and more distant relatives and, therefore, more and less eligible marriage partners.

13 Unlike Hutchinson, whose ethnographic research was conducted among the Nuer, Lambert (200o) studied substances and forms of kinship in India. 


\section{References}

AREND, Silvia Fávero. Amasiar ou Casar? A Familia popular no final do século XIX. Porto Alegre: UFGRS, 2001.

CARSTEN, Janet (ed). Culture of relatedness. Cambridge: Cambridge University Press, 2000.

DAL POZ, João. \& SILVA, Marcio F. Pequeno guia de referência da Máquina do Parentesco. São Paulo: Mimeo, 2009.

FERREIRA, Sérgio Luiz. Nós não somos de origem: populares de ascendência açoriana e africana numa freguesia do sul do Brasil (1780-1960).

UNIVERSIDADE FEDERAL DE SANTA CATARINA, Postgraduate Program in History. Florianópolis, Ph.D. thesis, 2006.

GIMENO, Silvia Inês Dufech. Destino viaja de barco: um estudo histórico, político e social da Costa da Lagoa e de seu processo de modernização 1930-199o. UNIVERSIDADE FEDERAL DE SANTA CATARINA, Postgraduate Program in Political Sociology. Florianópolis, MA dissertation, 1992.

GNACCARINI,J.C. O Rapto das Donzelas. São Paulo: USP (published in a shortened version in Tempo Social 1(1)), 1989.

GOODE, Willian J. A Familia. São Paulo: Livraria Pioneira Editora, 1970.

HERITIER, Françoise. Masculino Feminino: o pensamento da diferença. Lisbon: Instituto Piaget, 1992.

HUTCHINSON, Sharon Elaine. "Identity and substance: the broadening bases of relatedness among the Nuer of southern Sudan”. In: Culture of relatedness. Cambridge: Cambridge University Press, 2000.

LAMBERT, Helen. "Sentiment and substance in North Indian forms of relatedness”. In: Culture of relatedness. Cambridge: Cambridge University Press, 2000.

LOSEKANN, Maria Sandra. São João do Rio Vermelho: memória dos Açores em Santa Catarina. Porto Alegre: Escola Superior de Teologia e Espiritualidade Franciscana, 1989.

MALUF, Sônia. Encontros Noturnos: Bruxas, bruxarias na Lagoa da Conceição. Rio de Janeiro: Rosa dos Tempos, 1993.

PITT-RIVERS, Julian. A Antropologia da Honra ou Política dos Sexos: ensaios de antropologia mediterrânea. Barcelona: Crítica, 1979.

SAMARA, Erni de Mesquita. A Família Brasileira. São Paulo: Brasiliense, 1985. SILVA, Maria Beatriz Nizza da. Sistema de casamento no Brasil Colonial. São Paulo:EDUSP, 1984 . 
SILVA, Marineide Maria. "Isso é feio" "Isso é bonito": Casamento, fuga e honra em Ponta das Canas. (Undergraduate dissertation in Social Sciences) UNIVERSIDADE FEDERAL DE SANTA CATARINA. Florianópolis, 1994. STRATHERN, Marilyn. O Gênero da Dádiva: Problemas com as mulheres e problemas com a sociedade na melanésia. Campinas: Ed. Unicamp, 2006. WIGGERS, Raquel. "Sou daqui da Caieira da Barra do Sul": parentesco, familia, casa e pertença em uma localidade no sul do Brasil. Ph.D. in Social Sciences. UNICAMP. Campinas, 2006.

WOORTMANN, Klaas; WOORTMANN, Ellen.F. Fuga a Três Vozes. Anuário Antropológico 91. Rio de Janeiro: Tempo Brasileiro, 1993.

\section{About the author}

Juliana P. Lima Caruso

E-mail: ju.limacaruso@gmail.com

MA from the Postgraduate Programme in Social Anthropology of the Federal University of Santa Catarina.

\section{Publications}

CARUSO, J. P. L. Rendas de Relações: fuga, familia e parentesco na Costa da Lagoa. In: IX RAM-Culturas, Encontros e Desigualdades. 2011, Curitiba. IX RAMCulturas, Encontros e Desigualdades. 2011.

CARUSO, J. P. L. Parentesco e Casamento: da fuga ao morar junto na Costa da Lagoa, Florianópolis. In: Fazendo Gênero 9 : Diásporas, Diversidades, Deslocamentos., 2010, Florianópolis. Anais Eletrônicos- Fazendo Gênero 9, 2010.

CARUSO, J. P. L. Interditos matrimoniais: Os contextos da fuga no Rio Vermelho. In: Ram 2009, 2009, Buenos Aires. Ram 2009, 2009. 